\title{
Signs of grace (and opposite) for 1981
}

All new years are important. This, 1981 , will be crucially so. By next December, it should be clear how several influential governments are tackling the problems which now confront them. For the time being, the most absorbing question is whether $\mathrm{Mr}$ Ronald Reagan will live up to his election promises - and threats. Before the year is up, however, there should be a new government in the Soviet Union, Even when the fear that change means danger is as deeply ingrained as in Moscow, it is unthinkable that $\mathrm{Mr}$ Brezhnev will be kept on as president much longer. In Western Europe, the chances are that the same old governments will have to battle with the same old problems, but with a sense of mounting despair. If the problems of economic stagnation coupled with inflation appear as obdurate by the end of the year as they seem now, people will begin to behave as if these problems have come to stay. So what are the signs to look for in the months ahead?

Economic problems matter because they determine the resources available for existing, cherished, institutions and for innovation. The industrialized democracies now all suffer to some degree from the disease pioneered first by Italy and then by Britain - rapid inflation born of democratic voters' convictions that living standards must inexorably rise, even when productivity is falling or when resources are transferred in substantial amounts to OPEC oil producers. The consequences are all too clear industrial investment and research and development are starved of resources, productivity falls still further, the pool of wealth for sharing out diminishes and the dole queues lengthen. One of the first tests of Mr Reagan's temperament in of fice rather than on the hustings will be the fine print that will no doubt accompany his promised tax-cut. The promise is too fresh in people's minds to be forgotten, but a tax-cut unrequited by reduced federal expenditure would be inflationary. So will the of fsetting cuts be intelligent (housing subsidies, pointless environmental protection, excessive solar energy research), stupid (education, research and development) or - horror - non-existent? Other governments in industrialized countries are likely to take their cue from Washington. If $\mathrm{Mr}$ Reagan ducks the economic issues, many other governments will know that there is no point in their struggling separately against inflation.

The Soviet economic problem, outwardly different, is as worrying - and not exclusively for Soviet citizens. In the whole Soviet bloc, there is less wealth to share than the managers of the economy would like. Inflation is, by definition, not a problem. Whatever people's hopes, their shares of what is to be shared are determined by the system of allocation. One consequence is the grinding deprivation of much of the Soviet system, partly the cause of troubles such as those with which Poland has recently been beset. The question which the anonymous electors of $\mathrm{Mr}$ Brezhnev's successor will have to face is whether the new Soviet government should risk some relaxation of the domestic system for the benefits that would ultimately accrue in improved economic performance. Probably they will shrink from taking such a step on the grounds that the risks of relaxation would be immediate and the benefits delayed. That will be bad news both for citizens of the Soviet bloc and for the rest of us. The needless economic privations of Eastern Europe and beyond are not simply cruel to those who bear the brunt of them but part of the cause of continuing trouble between East and West.

The irony, both in the West and the East, is that the ingredients of continuing technical change and economic improvement are clearly apparent. The cost of petroleum has become a burden, but nuclear power stations are partially a substitute. The new computer technologies, wildly oversimplified though they may have been, are gathering dust for lack of investment capital and sufficiently skilled manpower. Communications technology, physical and electronic, is held back by lack of capital but also by regulatory bumbledom. Agriculture, surprisingly the great success of the industrialized West in recent decades, languishes elsewhere. The outstanding challenge for most governments in 1981 will be to make a fresh start on using these ingredients of prosperity to enable their people to feed, clothe and house themselves decently, and to have something left over to do what they like with. For many Western governments, but especially for the American, this will require something of a battle with the powerful lobbies which have grown up in the past decade and which appear, after all, to think that there is such a thing as a free lunch - the benefits of technology but no generating plants within sight or the benefits of new drugs but no experiments with animals please. Mr Reagan's reputation suggests that he might throw himself cheerfully into such a fight, but only time will tell.

Two other issues will be bellwethers for the coming year, with policies on defence and arms control most vividly in people's minds. Mr Reagan seems to be committed to winning the arms race, whatever that may mean. Nobody, not even the Soviet Union, will be surprised if the Pentagon's budget now grows again. People in Europe will bite their nails. The danger is that one side or the other will be tempted to check whether it is really winning by pressing all the buttons. The chances are, however, that the arms race of the 1980 s will not be very different from that of the $1950 \mathrm{~s}$ - the modern equivalent of sabre rattling, a diversion of resources from more constructive purposes but adventitiously a source of further technological innovation. What matters much more, especially where $\mathrm{Mr}$ Reagan is concerned, is whether he will have the wit and the courage (for a Republican) to seize the opportunity in arms control with which he has been presented. The new administration is committed to reopening Salt II, but Mr Reagan is not the out-and-out abrogator who began the election campaign. As Inauguration Day approaches, he will be made increasingly aware of the advantages, philosophical and political, from balancing his part in the arms race with an openminded view of what package might replace Salt 11 . The Comprehensive Test-Ban Treaty, nearly ready for signature though it is, is probably too much of a pill for the Republican Senate and General Alexander Haig to swallow. There is more room for manoeuvre on what are called theatre nuclear weapons - the missiles that must worry the West Germans but also, no doubt, Soviet military planners as well.

A less obvious sign of the way the wind is blowing in 1981 will be the way in which governments, but especially those of industrialized countries, shape in their dealings with the developing world. Mr Reagan's reputation is not encouraging but, to be fair, his position on the recommendations of the Brandt Report (as on many other issues) is not all that explicit. Again, the new president has the appearance of a conservative who may be pushed in liberal directions by events or even arguments. The obvious difficulty is that the months ahead are likely to see still more occasions on which developing countries act uppishly towards the United States (provoking pressure to put them in their place), but that there is no powerful political constituency for the decently self-interested policy of adequate assistance, technical and financial. In the long run, however, there will be no point in beating inflation or surviving the arms race ahead if the world that is left remains as dangerously divided into rich and poor. 